\title{
Genotoxicity in Zebrafish (Danio rerio) Exposed to two Pharmacological Products from an Impacted Italian River
}

\author{
Lucia Rocco',2*, Angelina Izzo', Giovanna Zito1, Carmela Peluso ${ }^{1}$ and Vincenzo Stingo ${ }^{1,2}$ \\ ${ }^{1}$ Department of Life Sciences, Second University of Naples, via Vivaldi 43, Caserta, Italy \\ ${ }^{2} \mathrm{C}-\mathrm{REACH}$, Interuniversitary Center Reach, University of Naples, Italy
}

\begin{abstract}
The aim of this study was to identify the pharmaceutical substances in the waters of the river Volturno in Campania and to identify the genetic alterations that they induce in fish. These vertebrates, living in water, are particularly sensitive to polluting substances dissolved in their water that interact with DNA leading to the formation of additions or breaks, as well as to the loss or chemical modifications of the bases, because they can conserve and concentrate the substances discharged into their natural habitat. A preventive chemical analysis was carried out on the waters of the river Volturno. The results showed the presence of various drugs, among which Carbamazepine, a known antiepileptic and Diclofenac, a non-steroid anti-inflammatory agent. The genotoxicity of these two compounds was evaluated in 155 individuals of Danio rerio using the Comet Test, the Diffusion Assay and RAPD-PCR. The alkaline version of the Comet Test was used for the erythrocytes of the zebrafish to evaluate the presence of DNA breaks of a single strand. Furthermore, the Diffusion Assay was used to estimate the number of apoptotic cells. The specimens were treated with Carbamazepine and Diclofenac at the same average concentrations found in the river Volturno and were killed after three, seven and fifteen days. The results of the Comet Test showed a statistically significant loss of DNA integrity after only three days of exposure to the drugs. Also the percentage of apoptotic cells reached its maximum values after three days of exposure to Carbamazepine and after one week to Diclofenac. By RAPD-PCR the genotoxicity was evaluated at the molecular level. The amplification products from the individuals exposed to the same concentrations of the environmental pollutants showed significant changes in their electrophoretic pattern with respect to the negative controls. The results of all three tests clearly show the genotoxicity of the compounds analyzed.
\end{abstract}

Keywords: Genotoxicity; Comet test; Diffusion Assay; RAPD-PCR; Zebrafish

\section{Introduction}

Environmental degradation, above all that which takes place through the accelerated release of synthetic chemical substances, is of increasing interest for today's society. While industrial pollutant emissions have been monitored for some time and are subject to frequent checks, drugs are a group of chemical agents that have received little attention as potential environmental pollutants.

Many drugs are extremely bioactive compounds and are unknowingly introduced into the environment as complex mixtures by many routes, especially in wastewaters (both treated and untreated). Certain pharmaceutically active compounds (such as caffeine, nicotine and aspirin) have been known for almost thirty years to be compounds discharged into the environment, especially in highly populated areas. A more complete picture has only recently emerged where it is evident that numerous drugs from a wide range of therapeutic categories can appear in the environment and even in drinking water (even if at very low concentrations), especially in natural waters that receive wastewaters $[1,2]$.

In particular, studies carried out over the last few years not only in Europe, i.e. Greece, Spain, Germany and Italy, but also in Brazil and the USA, have shown that chemical substances (in the form of secondary metabolites deriving from pharmaceutical products) that are found as contaminants in aquatic environments every year are always more numerous. For this reason the contamination of aquatic ecosystems and the consequent modifications of the balance of flora and fauna that live there, are recognized as one of the principal environmental emergencies [2-4].

A genotoxic agent is a substance that interacts directly or indirectly with DNA causing damage to its genetic structure. The exposure of an organism to a genotoxic substance can result in a class of genetic effects that cause alterations of the structure and function of its DNA [5]. One of the genetic effects caused by genotoxic agents is genetic mutation: this type of modification does not always lead to severe changes of the phenotype, but, on the other hand, it can have very severe effects, such as the accumulation of mutations in specific sites that can generate tumors. Moreover, genotoxic substances can alter DNA integrity causing strand breaks. The exposure to genotoxic substances can increase the possibility of DNA strand breaks with respect to normal cellular conditions [6]. Moreover, it must be remembered that a genotoxic substance can provoke various responses according to the biological system on which it acts and based on its intensity (concentration of the compound and exposure time).

Over the last few years there has been a notable increase in studies aimed at evaluating the genotoxic effects that certain substances, among which drugs, can induce on the organisms that directly or indirectly come into contact with them. In particular, the most used experimental model for the study of genomic damage caused by chemical and pharmacological substances is that of fish. These vertebrates, in fact, living in water, are particularly sensitive to pollutants and thus more

*Corresponding author: Lucia Rocco, Department of Life Sciences, Second University of Naples, via Vivaldi 43, Caserta, Italy, E-mail: lucia.rocco@unina2.it

Received September 02, 2011; Accepted October 19, 2011; Published October 21, 2011

Citation: Rocco L, Izzo A, Zito G, PelusoC, Stingo V (2011) Genotoxicity in Zebrafish (Danio rerio) Exposed to two Pharmacological Products from an Impacted Italian River. J Environment Analytic Toxicol 1:103. doi:10.4172/2161. 0525.1000103

Copyright: (c) 2011 Rocco L, et al. This is an open-access article distributed under the terms of the Creative Commons Attribution License, which permits unrestricted use, distribution, and reproduction in any medium, provided the original author and source are credited. 
Citation: Rocco L, Izzo A, Zito G, PelusoC, Stingo V (2011) Genotoxicity in Zebrafish (Danio rerio) Exposed to two Pharmacological Products from an Impacted Italian River. J Environment Analytic Toxicol 1:103. doi:10.4172/2161-0525.1000103

susceptible to eventual damage that these substances can cause to DNA. They can produce the formation of additions and/or breaks of genetic material and/or punctiform mutations including insertions, deletions or chemical modifications of the purine and pyrimidine nitrogen bases. All this takes place because fish are organisms that can metabolize, concentrate and bio-accumulate the contaminants present in water.

The aim of this study was to identify the drugs present in various regions of the river Volturno by means of chemical analysis of the waters and to evaluate the potential genotoxic damage, that Carbamazepine and Diclofenac, which were present in relatively high concentrations, could have on the fauna once in the aquatic ecosystem.

In particular, the alterations present at the genomic level following the exposure to the chemical substances were investigated. For this purpose, specimens of zebrafish (Danio rerio) were used. They were exposed to the action of the same average concentrations of the drugs found in the waters of the river Volturno, for 3, 7 and 15 days. To show the structural alterations of the DNA, the Comet Test, the Diffusion Assay and RAPD-PCR were used. The first two tests were often used in synergy to evaluate the relationship that exists between environmental contaminants and damage induced in genetic material of organisms that populate aquatic ecosystems today $[7,8]$.

\section{Materials and Methods}

\section{Collection of specimens from the waters of the river Volturno}

Six collections were made from the river Volturno in the sites of: Limatola, Capua, Grazzanise, Cancello-Arnone and Castelvolturno (Figure 1). For each collection site 5 liters of water were removed and analyzed for the presence of drugs and products for personal care following the methodology described. The water samples were kept at $4^{\circ} \mathrm{C}$ up to analysis.

\section{Analysis of pharmaceuticals in river waters}

River water samples were analyzed as previously reported by [9] Briefly, samples were filtrated by glass microfiber filter GF/D $2.7 \mu \mathrm{g}$ and extract by SPE solid phase extraction RP-18 Waters (Massachusetts, USA). Eluates were dried under an air stream and re-dissolved in $0.01 \%$ acetic acid in MilliQ water ( $\mathrm{pH}$ 3.5), then centrifuged, transferred to glass vials, and $10 \mu \mathrm{l}$ samples were injected with an LC/MS.

The LC/MS system consisted of electro-spray mass quattrod LC (Micromass, Manchester, UK) triple quadruple instrument operating in the negative and positive ion mode. HPLC separation was effected with a Phenomenex Luna C-18 column, $5 \mu \mathrm{m}$ particle size $(2.50 \times 4.60$ mm e.d.) and Phenomenex Luna C-18 pre-column (2.50x4mm e.d.).

For analysis eluent $\mathrm{A}$ was constituted by $0.1 \%$ formic acid in MilliQ water, eluent B by acetonitrile. Elution started with $100 \%$ of eluent A followed by a 10 min linear gradient to $100 \%$ of eluent B, 2 min isocratic elution and a 2 min linear gradient to $100 \%$ of eluent $A$, which was maintained for $6 \mathrm{~min}$ to equilibrate the column.

The determination of the pharmaceuticals in the Volturno river waters was obtained by comparison with pure standards (SIGMA Aldrich).

\section{Genotoxicity assays}

The tests were carried out on 155 adult individuals of zebrafish (Danio rerio, Hamilton, 1822) bought from a local supplier; they were allowed to stabilize for two weeks before beginning the experiment. They were transferred to small tanks each containing 5 liters of water, in which the drugs were dissolved at the average concentrations found in the waters of the river Volturno (Table 1). In the same Table the various groups into which the specimens of Danio rerio were subdivided are reported. Specimens were also kept in uncontaminated water to study the polymorphisms within the same species and individuals exposed to water containing benzene (known genotoxic agent and thus used as internal control) [10] at the concentration of $10 \mu \mathrm{l} / \mathrm{l}$, in which exposure continued for 3,7 and 15 days.

At the end of exposure, the genotoxicity of these two drugs was evaluated by means of the Comet Test and the Diffusion Assay according to the methodology described by [7] and by means of RAPDPCR according to [11].

The Comet Test uses electrophoresis in an alkaline environment of single cells on agarose gel. The methodology required the removal of few

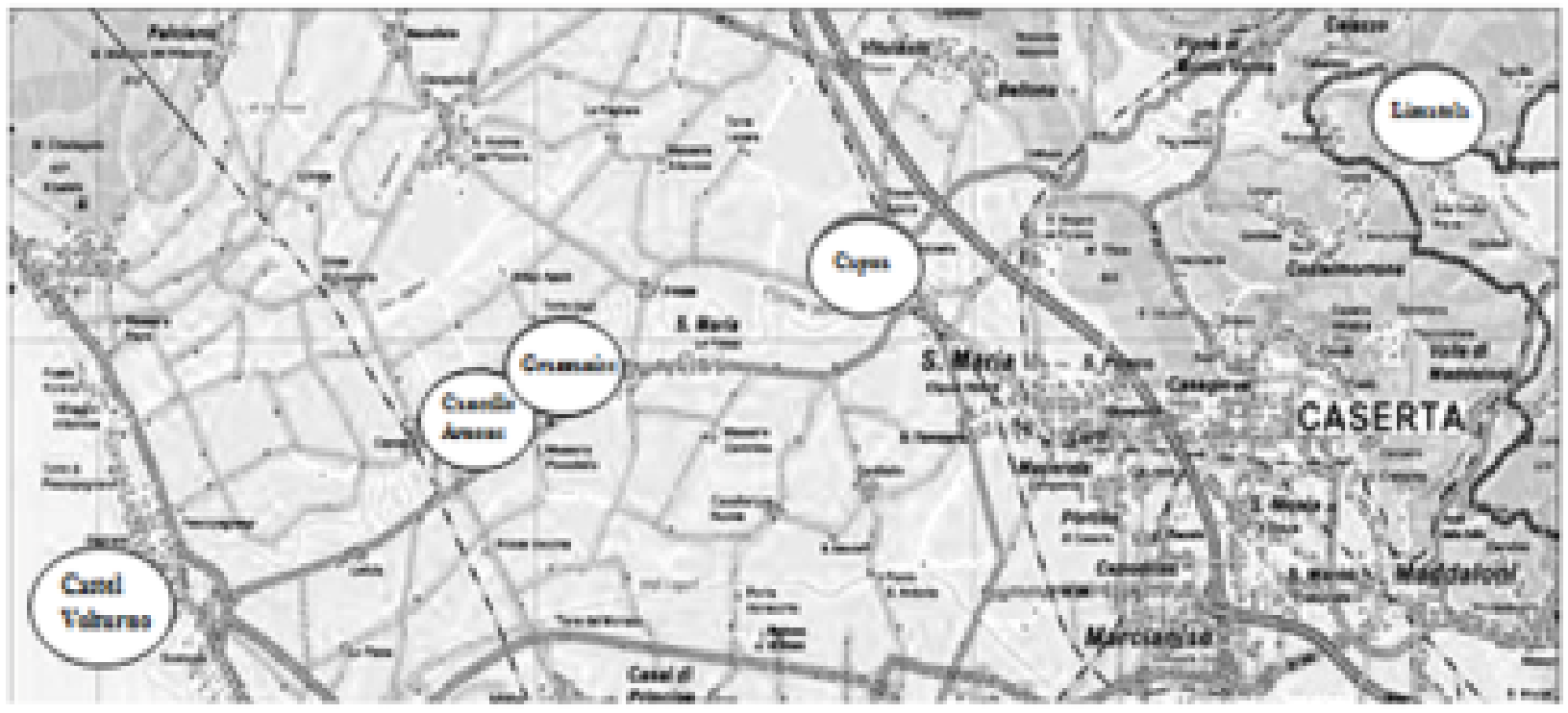

Figure 1: Map of Volturno River. The collection sites are circled. 
Citation: Rocco L, Izzo A, Zito G, PelusoC, Stingo V (2011) Genotoxicity in Zebrafish (Danio rerio) Exposed to two Pharmacological Products from an Impacted Italian River. J Environment Analytic Toxicol 1:103. doi:10.4172/2161-0525.1000103

\begin{tabular}{|l|l|l|l|}
\hline $\begin{array}{l}\text { Pharmaceutical } \\
\text { compound }\end{array}$ & $\begin{array}{l}\text { Mean concentration } \\
(\boldsymbol{\mu g} / \mathbf{L})\end{array}$ & $\begin{array}{l}\text { Days of } \\
\text { treatment }\end{array}$ & $\begin{array}{l}\text { Number of specimen } \\
\text { examined }\end{array}$ \\
\hline Carbamazepine & 0,31 & 3 & 26 \\
& & 7 & 26 \\
\hline & 15 & 26 \\
\hline Diclofenac & 0,18 & 3 & 26 \\
& & 7 & 25 \\
\hline
\end{tabular}

Table 1: Experimental conditions of treatment with Carbamazepine and Diclofenac.

microliters of blood from the zebrafish from below the gills, (the first organ exposed to contaminants during respiration), with a heparinized syringe to avoid coagulation; the hematic cells were then mixed with $500 \mu \mathrm{l}$ of 1X PBS (Phosphate Buffered Saline) and then centrifuged at $2000 \mathrm{rpm}$ for $10 \mathrm{~min}$. The supernatant was removed and $300 \mu \mathrm{l}$ of Low Melting Point Agarose (LMPA) $0.5 \%$ in $1 \mathrm{X}$ PBS was added to the pellet. Seventy-five $\mu \mathrm{l}$ of the above mentioned mixture was placed on slides previously coated with Normal Melting Point Agarose (NMPA) $1 \%$ in $1 \mathrm{X}$ PBS and then covered with glass covers $(24 \times 50 \mathrm{~mm})$, briefly equilibrated to $37^{\circ} \mathrm{C}$ prior to mixing to avoid the formation of bubbles and left at $4^{\circ} \mathrm{C}$ for $30 \mathrm{~min}$. The glass covers were removed and $85 \mu \mathrm{l}$ of LMPA at $37^{\circ} \mathrm{C}$ were added; the slides were warmed to $37^{\circ} \mathrm{C}$ for a few seconds and left for further $30 \mathrm{~min}$ at $4^{\circ} \mathrm{C}$. The slides immersed were maintained at $4^{\circ} \mathrm{C}$ for $60 \mathrm{~min}$ in a lysis solution at $\mathrm{pH} 10$, pre-cooled to $4^{\circ} \mathrm{C}$ and kept in the dark (to avoid damage from the light) until use. The lysis solution contained $\mathrm{NaCl} 2.5 \mathrm{M}$, Na 2 EDTA $0.1 \mathrm{M}$, Tris-Base $0.4 \mathrm{M}$, TRITON-X100 1\% and DMSO 10\%. After $60 \mathrm{~min}$ incubation the slides underwent denaturation for $10 \mathrm{~min}$ at room temperature in the electrophoresis buffer ( $\mathrm{NaOH} 10 \mathrm{~N}$ and EDTA $200 \mathrm{mM}$, pH 12.1), which creates the lesions to the DNA single filaments at the level of the labile sites following the exposure to the oxidating agents. The unraveled and relaxed DNA then migrated out of the nucleus during electrophoresis at $25 \mathrm{~V}$ and $300 \mathrm{~mA}$ for $15 \mathrm{~min}$. After electrophoresis, the slides were placed for $15 \mathrm{~min}$ in a neutralizing solution of Tris$\mathrm{HCl} 0.4 \mathrm{M}$ at $\mathrm{pH}$ 7.5. Finally, the slides, removed from the neutralizing solution, were fixed in cold methanol $100 \%$ for 3-5 min, and left to air-dry. The slides were then stained with $100 \mu$ of ethidium bromide $30 \mathrm{X}(10 \mu \mathrm{g} / \mathrm{ml})$, covered by a glass cover and read at the fluorescence microscope (Nikon Eclipse E-600) with an excitation filter BP 515$560 \mathrm{~nm}$ and a restriction filter LP $580 \mathrm{~nm}$. The images were acquired using a specific program (Komet version 6.0.0, Kinetic Imaging). The cells that had undergone DNA damage appeared as comets, with a tail of fragmented and decondensed DNA, while the control cells had a rounder and condensed nucleus. The migration of the DNA is a function of the number of breaks and the tail length [12]. The level of DNA fragmentation obtained by Comet assay was quantified by fluorescence microscopy and image analysis as the percentage of DNA migrating out of the nucleus (tail DNA). For statistical analysis was used the multifactor analysis of variance (MANOVA) $(\mathrm{p} \leq 0.05)$.

The Diffusion Assay clearly discriminates apoptotic cells from necrotic cells. Its experimental protocol is the same as that of the Comet Test, with only one difference: the slides do not undergo to electrophoresis. The cells with damaged DNA have a nucleus of reduced dimensions with DNA projections, whose extension is proportional to the genetic damage [13].

The RAPD (Random Amplified Polymorphism DNA)-PCR technique is simple, sensitive and effective in identifying DNA damage by means of a random amplification of fragments using PCR [14]. We used puREtaq Ready-to-go-PCR (GE Healthcare), which contains nucleotides (dNTPs) and Taq DNA recombinant polymerase (2.5 units). It is necessary to add DNA (40 ng) and the primer
(5'-d[CCCGTCAGCA]-3') [11] at the concentration of $5 \mathrm{pmol} / \mu \mathrm{l}$. The final volume of reaction was $25 \mu \mathrm{l}$. The chosen primer was selected for yielding amplification products with a reasonable number of bands and, above all, high definition and reproducibility. The amplification reaction followed this cyclic program: one initial step $\left(5 \min\right.$ to $\left.95^{\circ} \mathrm{C}\right)$, then 45 cycles including $1 \mathrm{~min}$ to $95^{\circ} \mathrm{C}, 1 \mathrm{~min}$ to $36^{\circ} \mathrm{C}$ and $2 \mathrm{~min}$ to $72^{\circ} \mathrm{C}$. Fragments of different length were generated due to the various pairings of the primer that can be seen by means of electrophoresis $(85 \mathrm{~V})$ on $3 \%$ agarose gel as bands. The change in the number of the bands and the variation in their intensity are associated with alterations of genetic material [15]. Before proceeding with the amplification reaction the DNA template was extracted from the muscle of each zebrafish (using an experimental protocol with a series of passages in chloroform and isopropanol, which guarantee a sufficiently pure extraction to produce a RAPD-PCR profile of good quality [14].

The polymorphic pattern generated by RAPD-PCR profiles allowed to calculate Genomic Template Stability (GTS, \%) as following:

$$
\text { GTS }=(1-\mathrm{a} / \mathrm{n}) \times 100
$$

where $a$ is the average number of polymorphic bands detected in each exposed sample and $n$ the number of total bands in the non treated samples. Polymorphism in RAPD profiles included disappearance of a band and appearance of a new band respect to the control.

The average was calculated for each experimental group exposed to different drug treatments. Changes in these values were considered as a percentage of their controls (set to $100 \%$ ).

The statistical analyses were carried out using the package software SPSS 9.05 for Windows [16].

\section{Results}

\section{Pharmaceutical agents found in the river Volturno}

The chemical investigation of the Volturno river waters identified four pharmaceutical products, bezafibrate, Carbamazepine, Diclofenac and metoloprolo, as reported in Table 2.

Two of these pollutants were found in larger quantities, Diclofenac, a non-steroidal anti-inflammatory drug and Carbamazepine, an anticonvulsant and mood stabilizing drug. For these reasons we choose to test only the genotoxicity effects of these two molecules.

\section{Comet test}

In Table 3 are reported the results coming from Comet Test. The specimens exposed to Carbamazepine at the concentration of $0.31 \mu \mathrm{g} / \mathrm{L}$ for 3 and 7 days had a percentage of damaged DNA significatively higher $(p \leq 0.05)$ with respect to the control fish. After 3 days of exposure, this concentration of the drug caused a statistically significant loss of DNA integrity of $65.5 \%$. The DNA damage decreased after 7 days of exposure of the zebrafish to Carbamazepine showing a loss of integrity of $61.0 \%$. Finally, the exposure extended to 15 days showed a decrease in the percentage of DNA damage (32.9\%).

\begin{tabular}{|l|l|}
\hline Pharmaceutical compound & Mean concentration $(\boldsymbol{\mu g} / \mathbf{L}) \pm S D$ \\
\hline Bezafibrate & $0.058 \pm 0.004$ \\
\hline Diclofenac & $0.180 \pm 0.015$ \\
\hline Metoprolol & $0.050 \pm 0.002$ \\
\hline Carbamazepine & $0.310 \pm 0.033$ \\
\hline
\end{tabular}

$\mathrm{SD}=$ Standard Deviation

Table 2: Pharmaceutical compounds chemically revealed in Volturno waters together with their relative average concentrations. 
Citation: Rocco L, Izzo A, Zito G, PelusoC, Stingo V (2011) Genotoxicity in Zebrafish (Danio rerio) Exposed to two Pharmacological Products from an Impacted Italian River. J Environment Analytic Toxicol 1:103. doi:10.4172/2161-0525.1000103

Page 4 of 7

\begin{tabular}{|l|l|l|l|}
\hline $\begin{array}{l}\text { Pharmaceutical } \\
\text { compound }\end{array}$ & $\begin{array}{l}\text { Days of } \\
\text { treatment }\end{array}$ & $\begin{array}{l}\text { Tail DNA \% } \\
\mathbf{\pm S D}\end{array}$ & $\begin{array}{l}\text { \% of apoptotic cells } \\
\mathbf{\pm S D}\end{array}$ \\
\hline Untreated & 3 & $23.7 \pm 4.68$ & $1.5 \pm 0.1$ \\
& 7 & $24.1 \pm 2.73$ & $1.4 \pm 0.1$ \\
\hline Carbamazepine & 15 & $23.2 \pm 3.35$ & $1.6 \pm 0.3$ \\
$(0.31 \mu \mathrm{g} / \mathrm{L})$ & 7 & $65.5 \pm 5.11^{*}$ & $9.2 \pm 0.9^{*}$ \\
& 15 & $61.0 \pm 4.62^{*}$ & $8.9 \pm 0.9^{*}$ \\
\hline $\begin{array}{l}\text { Diclofenac } \\
(0.18 \mu \mathrm{g} / \mathrm{L})\end{array}$ & 3 & $32.9 \pm 3.62^{*}$ & $4.6 \pm 0.4^{*}$ \\
& 7 & $44.9 \pm 3.78^{*}$ & $2.8 \pm 0.2$ \\
& 15 & $56.7 \pm 5.06^{*}$ & $8.7 \pm 0.8^{*}$ \\
\hline
\end{tabular}

$\mathrm{SD}=$ Standard Deviation

Table 3: Percentage of DNA in the tail and of apoptotic cells in Danio rerio erythrocytes exposed to Carbamazepine and Diclofenac $\left({ }^{*} P \leq 0.05\right)$.

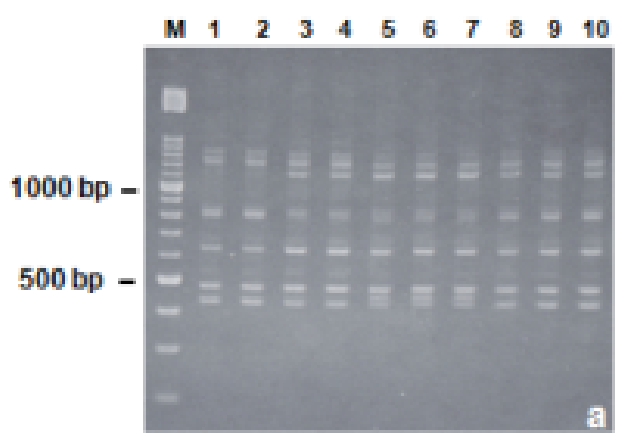

$\begin{array}{lllllllllll}M & 1 & 2 & 3 & 4 & 5 & 6 & 7 & 8 & 9 & 10\end{array}$
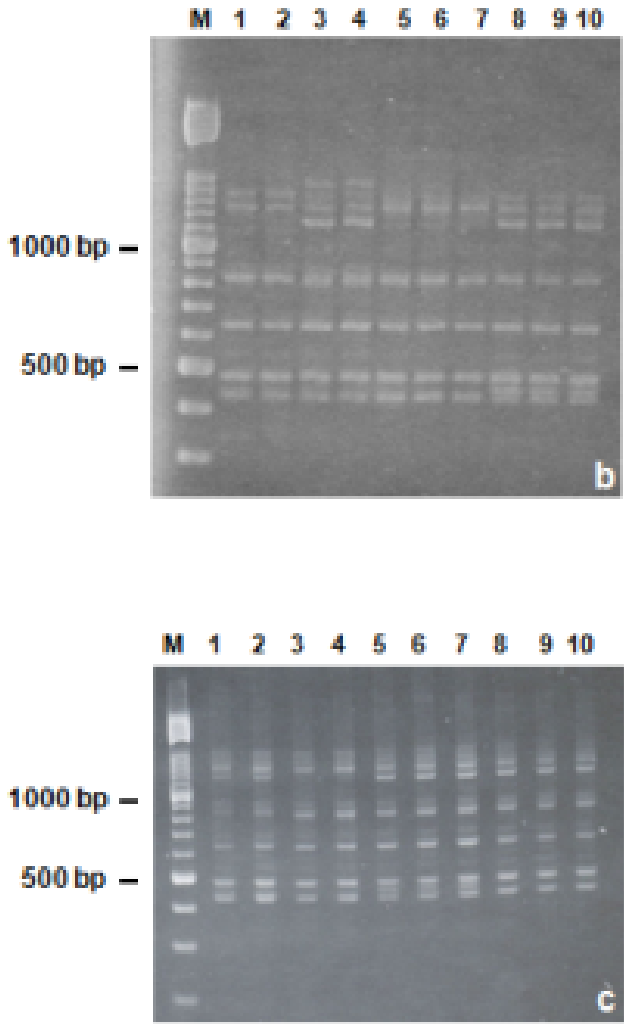

Figure 2: RAPD-PCR pattern of DNA samples treated with the pharmacological substances. RAPD-PCR of Danio rerio genomic DNA after 3 days (a), 7 days (b) and 15 days of exposure (c). M= marker $100 \mathrm{bp}$ ladder; $1-2=$ non treated fish; 3-4 = treated with benzene ; 5-6-7 = treated with Diclofenac; 8-9-10 = treated with Carbamazepine.
As regards the exposure to Diclofenac at the concentration of $0.18 \mu \mathrm{g} / \mathrm{L}$ for 3 and 7 days the results indicate that the percentage of damaged DNA was significatively $(p \leq 0.05)$ higher with respect to that of the control fish. After 3 days of exposure, this concentration of the drug caused a statistically significant loss of DNA integrity of $44.9 \%$. The DNA damage increased after 7 days of exposure $(56.7 \%)$. The exposure for 15 days showed a decrease in the percentage of DNA damage of $32.9 \%$

\section{Diffusion assay}

The induced DNA damage after Diffusion Assay was seen as the formation of apoptotic cells and their percentage was calculated. Table 3 shows that the fish exposed to the two drugs for 3 and 7 days had a higher percentage of apoptotic cells with respect to the control fish. After 3 days of exposure, the concentrations caused a significative loss of DNA integrity with consequent apoptosis of $9.2 \%$ for Carbamazepine and $2.8 \%$ for Diclofenac. The percentage of the apoptotic cells decreased slightly after 7 days of exposure of the zebrafish to Carbamazepine reaching $8.9 \%$, while it increased for Diclofenac (8.7\%). The exposure at 15 days showed a decrease of the percentage of apoptotic cells of $4.6 \%$ for Carbamazepine and 5.0\% for Diclofenac.

\section{RAPD-PCR}

The amplification products from RAPD-PCR showed various bands of length between 300 and $1500 \mathrm{bp}$. The bands at about 400 $500,600,800$ and $1300 \mathrm{bp}$ were present in all the controls. The results indicate that the primer used possessed a high efficiency to amplify the genomic DNA of the zebrafish.

In particular, after three days of exposure to Diclofenac there were two new bands at about 470 and 1100 bp (Figure 2a), while those exposed to Carbamazepine showed only one new band at about 1100 bp. After seven days of exposure the specimens exposed to Diclofenac showed the loss of the band at about $1400 \mathrm{bp}$, while those exposed to Carbamazepine showed two new bands with respect to the controls, at about 470 and about $1100 \mathrm{bp}$ (Figure 2b). After fifteen days of exposure to Diclofenac there was a further band at about $470 \mathrm{bp}$, while those exposed to Carbamazepine showed a reduction of the bands at about 1400 and $1500 \mathrm{bp}$ (Figure 2c). Changes in the RAPD patterns were expressed as decreases in GTS, a qualitative measure reflecting the change to the number of RAPD profiles generated by the two drugs, in relation to profiles obtained from the control specimens. GTS values were reported in Table 4.

\section{Discussion}

Aquatic pollution due to the discharge of chemical substances, among which are active pharmacological agents, into aquatic ecosystems is becoming a threat for the environment. The active pharmacological agents discharged into superficial waters can, in fact,

\begin{tabular}{|l|l|l|}
\hline Pharmaceutical compound & Days of treatment & GTS \% \\
\hline \multirow{2}{*}{ Untreated } & 3 & 100 \\
& 7 & 100 \\
\hline Carbamazepine & 15 & 100 \\
$(0,31 \mu \mathrm{g} / \mathrm{L})$ & 3 & 70 \\
& 7 & 65 \\
\hline Diclofenac & 15 & 59 \\
$(0,18 \mu \mathrm{g} / \mathrm{L})$ & 3 & 95 \\
\hline
\end{tabular}

Table 4: Changes of GTS in Danio rerio erythrocytes exposed to Carbamazepine and Diclofenac as evidenced by RAPD-PCR. 
interact with the DNA of the organisms that make up the trophic chain of these environments and induce significative genetic damage.

There have been numerous studies carried out on both superficial waters in which it has been shown that among the chemical compounds found in superficial waters, and thus responsible for their contamination, there are many active pharmacological agents; the chemical characterization of these agents has allowed us to conclude that among the drugs found with the greatest frequency are analgesics and anti-inflammatory drugs, but also antibiotics and/or bacteriostatic drugs, antiepileptics, $\beta$-blockers, hematic regulators of lipids, and oral contraceptives [2-4].

These studies have shown the degree of environmental problems, making the authorities in charge of their control and safeguard seriously evaluate their presence and above all their toxicity and the effect they could have on the flora and fauna of aquatic ecosystems.

Carbamazepine and Diclofenac, as other pharmaceutical compounds, enter the surface water, because they are only partially eliminated in wastewater treatment plants [17]. In fact Carbamazepine showed a very low elimination rate $(7 \%)[18,19]$, seems to be very persistent and some authors have observed only a slight removal by phototransformation [20]. For Diclofenac, laboratory tests performed with the lake water showed a good elimination through phototransformation, but this process is strongly time and site specific and can vary enormously [17]

The main mechanism of action of Diclofenac for the induction of cyto and genotoxicity is probably due to an increase of oxidative stress. In fact, several authors have demonstrated that the mechanism of Diclofenac-induced mitochondrial injury seems to involve the generation of reactive oxygen species (ROS) causing oxidative stress. [21]. This could indicate that the production of ROS and the consequent oxidative stress due to Diclofenac could be responsible for the observed DNA damage. The drug can directly produce the observed DNA damage also by means of the creation of adducts and/or intercalants without significant ROS production [22].

On the other hand, the mechanism of Carbamazepine-induced genotoxicity, as of other antiepileptics, resides in the possibility that it can cause folate deficiency, and this has been proposed as a possible teratogenetic cause. Biochemical studies have suggested that disturbances in the nucleotide pool, DNA synthesis, and cell growth are responsible for the adverse effects associated with folate deficiency. It has known that folate deficiency causes expression of chromosomal fragile sites, chromosome breaks, micronucleus formation and DNA hypomethylation [23].

Diclofenac has known toxic and genotoxic effects in non-target organisms, like fish, where it can bioaccumulate and change cellular reactions in liver, kidney and gills [24-26] and mussels [27-29].

The cytotoxicity, genotoxic potentials and mutagenic activities of Carbamazepine have been poorly understood and little investigated. At this time only few evidences have been reported in literature [30]. Some adverse affects of Carbamazepine are enzyme-induction and interaction with other drugs, as well as the increase in the incidence of congenital malformations [31,32]. Some reports indicate that Carbamazepine induces apoptosis in cultured cerebellar granule cells [33].

Laville et al. [34] found that Carbamazepine was cytotoxic in primary cultures of rainbow trout hepatocytes and induced oxidative stress. Celik [35] demonstrated the in vitro genotoxicity of Carbamazepine using cytokinesis-block (CB) micronucleus assay in human blood lymphocytes.
Electrophoresis in the alkaline environment of single cells on agarose gel (Alkaline Single Cell Gel Assay), also known as the Comet Test, is a very accurate technique that quantifies, not only the damage to genetic material, but also the eventual degree of repair [12,36]. This is a rapid and very sensitive technique that allows the study of the factors that cause mutagenicity and carcinogenicity, and, over the last few years, has quickly become an important technique in various sectors of science such as genetic toxicology. In particular, the Comet Test is used for the study of damage caused by genotoxic agents and/or mutagens, endogenous and/or exogenous on genetic material, evaluating damage of various nature (mutations or breaks) of genetic material. The Comet Test also has the great advantage of needing only a small quantity of organic material (few microliters of blood) and can be carried out on an extremely low number of nucleated cells (from some hundreds to few thousands), sufficient to give an adequate statistical analysis $[8,37,38]$.

The Diffusion Assay is a modified version of the Comet Test and is very sensitive in estimating the degree of apoptosis in isolated cells [39]. The cells with DNA damage are clearly defined and have larger nuclei with the projection of DNA inside [40].

Molecular genetics has provided a good number of innovative techniques to measure genotoxicity. The RAPD (Random Amplified Polymorphism DNA) technique introduced by Williams et al. [41] and by Welsh and McClelland [42] is a technique that studies the amplification of random segments of genomic DNA by means of PCR.

The polymorphisms of the random amplification of DNA represents the corresponding polymorphic traits of genomic DNA. As described in literature, the damage caused to genomic DNA could introduce modifications of the binding sites of the aspecific primers used, causing the presence of various electrophoretic patterns of PCR (polymorphisms) [11,14, 43,44].

These findings make the use of this method possible to investigate the eventual genotoxicity of pollutants [45-47]. As for other methods that use biological imaging for toxicological analysis, RAPD-PCR could provide more precise conclusions for specimens being investigated with respect to a merely numeric technique, which reduces data into discreet elements and differentiates the imaging patterns only by means of mathematical and statistical methods.

In 2004 Zhiyi and Haowen [11] demonstrated, using this technique and the experimental model of zebrafish (Danio rerio), that some aquatic contaminants such as phosphamide and dimethoate are able to induce genotoxicity, confirming the accuracy and the sensitivity of this technique for the analysis of genotoxic damage induced by environmental contaminants. The technique was used with success by our group to evaluate the genotoxicity of several drugs found downstream of some Italian wastewater treatment plants $[7,47]$.

The aim of our research had the specific objective of evaluating the potential genetoxicity of two drugs, Carbamazepine (an antiepileptic) and Diclofenac (an anti-inflamatory drug) present in the waters of the river Volturno. As experimental model we used zebrafish (Danio rerio), not only because fish are a component of the trophic chain of the waters of the ecosystem being studied, but also because there have been many studies in literature that use these vertebrates as bio-indicators for studies on genetic toxicology $[7,11,47]$. The genetic damage was evaluated using three tests, the Comet Test, the Diffusion Assay and RAPD-PCR, and to detect eventual damage induced at the genomic level, the zebrafish were exposed to the same average concentrations of Carbamazepine and Diclofenac found in the river Volturno. The methods that are generally used to evaluate mutational damage induced 
by xenobiotic substances, such as the Test of Ames, do not always detect genotoxic damage. However, in 2001 Snyder and Green [48] reported that various drugs such as Diclofenac and Carbamazepine induce genotoxic effects that are not detectable with the test of mutagenesis of Ames, but showed positivity to the test of carcinogenesis.

From the analysis of the results of the Comet Test it can be seen that Carbamazepine at the concentration of $0.31 \mu \mathrm{g} / \mathrm{L}$ induces a fragmentation of DNA even after a short period of exposure (3 days) and that the extension of exposure to antiepileptics caused not only a decrease of the damage in each cell after 7 days of exposure, but there was also a certain repair of the damage after 15 days of exposure to the drug. These results are in agreement with the Diffusion Assay, given that also the percentage of the apoptotic cells increased in the first 3 days in relation to the period of exposure and began to decrease after 7 days of exposure, showing a repair of the damage after 15 days of exposure to the drug.

From the results of the Test Comet it can be seen that also Diclofenac at the concentrations assayed was capable of inducing genetic damage in a short time (after only 3 days of exposure), damage that continued to increase after 7 days of exposure, there then followed a certain repair of the damage after 15 days of exposure. Also in this case the results agree with those obtained with the Diffusion Assay: the percentage of apoptotic cells increased after 3 and 7 days of exposure to the drugs, while there was a notable decrease after 15 days of exposure, confirming a repair of the damage.

As regards RAPD-PCR, instead, we characterized the RAPD bands present in different number and/or intensity in fish exposed to the two compounds with respect to the untreated specimens. The appearance or loss of the amplification products of PCR can reveal a change in the sequence of DNA due to mutations, showing new events of annealing and/or of great of deletions, bringing two pre-existing sites closer or making them farther apart. Moreover, the pattern of amplification of the DNA of the individuals exposed revealed the acquisition or the loss of bands and/or the change of intensity of the same bands, referable to a variation in the number of recognition sites of the sequence of the primer and thus of mutations. The variations of frequency of the bands could be the result of structural changes induced by genotoxic events. In fact, the changes in the electrophoretic pattern reflect the alterations of DNA due to the single changes of bases (punctiform mutations) or a more complex chromosomal reorganization [11].

Analogously, in this study, the DNA damage induced by Carbamazepine and Diclofenac are seen by means of changes in the variation of the intensity of the bands and the loss and/or acquisition of new bands. Furthermore, RAPD-PCR confirmed that the DNA damage induced by these drugs at the concentrations used was already evident after three days of exposure.

The RAPD-PCR method showed, after 15 days of exposure with the drugs, the presence of genetic modifications. In this case there was no restoration of the original pattern of amplification after 15 days of exposure with both drugs and no repair of the damage. The loss or the presence of new bands could, on the one hand, indicate that the damage had not yet been repaired or, that the change of the number of bands could be interpreted as an attempt to create "a lessening of the mutations" able to confer resistance to the individuals exposed for long periods to the tested compounds [49].

Taken together, the data obtained from the Comet Test, the Diffusion Assay and RAPD-PCR show that the three drugs at the concentrations found in the river Volturno exert a significant genotoxic action already after three days of exposure. The analysis of the data, moreover, suggests that the genotoxicity of the two above-mentioned drugs is based on the time of exposure: in fact, both Carbamazepine and Diclofenac showed increasing DNA damage of the zebrafish after 3 and 7 days of exposure and a repair of the damage after 15 days of exposure to these drugs.

Finally, the relationship that exists between environmental contamination and damage induced in the genetic material of the organisms that populate the aquatic ecosystems is today often evaluated by a synergic approach using the Comet Test, the Diffusion Assay and RAPD-PCR simultaneously; this is due to the capacity of these tests to discriminate genotoxic agents and to their high sensitivity.

\section{Acknowledgements}

We would like to express our gratitude to Dr. Antony Bridgewood for his assistance in revising the English of this manuscript.

The present research was supported by CAMPANIA REGION (Italy) grants

\section{References}

1. Carballa M, Omil F, Lema JM, Llompart M, Garcia-Jares C, et al. (2004) Behavior of pharmaceuticals, cosmetics and hormones in a sewage treatment plant. Water Res. 38: 2918-2926.

2. Pomati F, Orlandi C, Clerici M, Luciani F, Zuccato E (2008) Effects and interactions in an environmentally relevant mixture of pharmaceuticals. Toxicol. Sci 102: 129-137.

3. Stan HJ, Heberer TH. (1997) Pharmaceutical in the aquatic environment. In Suter M.J.F. (Eds.), Dossier Water Analysis, Analysis 25: M20-M23.

4. Halling-Sørensen B, Nielsen N, Lanzky PF, Ingerslev F, Hansen L et al. (1998) Occurence, fate and effects of pharmaceutical substances in the environment - a review. Chemosphere 36: 357-393.

5. Shugart LR.(1990) Biological monitoring: testing for genotoxicity. In McCarthy J. and Shugart L.R (Eds.), Biological Markers of Environmental Contaminants. Boca Raton, FL Lewis. Publishers Inc. 12: 353-360.

6. Shackelford RE, Kaufmann WK, Paules RS (1999) Cell cycle control, checkpoin mechanisms, and genotoxic stress. Environ. Health. Perspect. 107: 5-24.

7. Rocco L, Frenzilli G, Fusco D, Peluso C, Stingo V. (2010) Evaluation of zebrafish DNA integrity after exposure to pharmacological agents present in aquatic environments. Ecotoxicol Environ Saf 73: 1530-1536.

8. Frenzilli G, Falleni A, Scarcelli V, Del Barga I, Pellegrini S et al. (2008) Cellular responses in the cyprinid Leuciscus cephalus from a contaminated freshwater eco system. Aquat. Toxicol. 89: 188-196.

9. Zuccato E, Calamari D, Natangelo M, Fanelli R. (2000) Presence of therapeutic drugs in the environment The Lancet 335: 1789-1790.

10. Whysner J, Reddy MV, Ross PM, Mohan M, Lax EA. (2004) Genotoxicity of benzene and its metabolites. Mutat Res 566: 99-130.

11. Zhiyi R, Haowen Y. (2004) A method for genotoxicity detection using random amplified polymorphisms DNA with Danio rerio Ecotox. Environ. Saf. 58: 96 103

12. Singh NP, McCoy MT, Tice RR, Schneider EL. (1998) A simple technique for quantitation of low levels of DNA damage in individual cells. Exp Cell Res 175 184-191.

13. Gichner T, Mukherjee A, Wagner ED, Plewa, MJ. (2005) Evaluation of the nuclear DNA Diffusion Assay to detect apoptosis and necrosis. Mutat Res 586: 38-46.

14. Atienzar FA, Jha AN. (2006) The random amplified polymorphic DNA (RAPD) techniques applied to genotoxicity and carcinogenesis studies: a critical review. Mutat Res 613: 76-102.

15. Noel S, Rath SK. (2006) Randomly amplified polymorphic DNA as a tool for genotoxicity: an assessment. Toxicol Ind Health 22: 267-75.

16. Liu W, Yang YS, Zhou Q, Xie L, Li P, et al. (2007) Impact assessment of cadmium contamination on rice (Oryza sativa L.) seedlings at molecular and population levels using multiple biomarkers. Chemosphere 67: 1155-1163. 
Citation: Rocco L, Izzo A, Zito G, PelusoC, Stingo V (2011) Genotoxicity in Zebrafish (Danio rerio) Exposed to two Pharmacological Products from an Impacted Italian River. J Environment Analytic Toxicol 1:103. doi:10.4172/2161-0525.1000103

17. Tixier C, Singer HP, Oellers S, Muller SR (2003) Occurrence and fate of Carbamazepine, clofibric acid, Diclofenac, ibuprofen, ketoprofen, and naproxen in surface waters. Environ Sci Technol 37: 1061-1068.

18. Ternes TA (1998) Occurrence of drugs in German sewage treatment plants and rivers. Water Res 32: 3245-3260.

19. Stumpf M, Ternes TA, Wilken RD, Rodrigues SV, Baumann W (1999) Polar drug residues in sewage and natural waters in the state of Rio de Janeiro. Brazil Sci Tot Envir 225:135-141.

20. Andreozzi R, Marotta R, Pinto G, Pollio A. (2002) Carbamazepine in water: persistence in the environment, ozonation treatment and preliminary assessment on algal toxicity. Water Res. 36: 2869-2877.

21. Gomez-Lechon MJ, Ponsoda XOCE, Donato T, Castell JV, Jover R (2003) Diclofenac induces apoptosis in hepatocytes by alteration of mitochondria function and generation of ROS. Biochem Pharmacol 66: 2155-2167.

22. Haap T, Triebskorn R, Kohler HR. (2008) Acute effects of Diclofenac and DMSO to Daphnia magna: Immobilisation and hsp70-induction. Chemosphere 73: 353- 359.

23. Fenech M, Crott JW (2002) Micronuclei, nucleoplasmic bridges and nuclea buds induced in folic acid deficient human lymphocytes-evidence for breakagefusion-bridge cycles in the cytogenesis-block micronucleus assay. Mutat. Res. 504:131-136.

24. Hoeger B, Kollner B, Dietrich DR, Hitzfeld B (2005) Water-borne Diclofenac affects kidney and gill integrity and selected immune parameters in brown trout (Salmo trutta f. fario). Aquat Toxicol 75: 53-64

25. Schwaiger J, Ferling H, Mallow U, Wintermayr H, Negele RD (2004) Toxic effects of the non-steroidal anti-inflammatory drug Diclofenac part 1: histopathological alterations and bioaccumulation in rainbow trout. Aquat Toxicol 68: 141-150.

26. Triebskorn R, Casper H, Heyd A, Eikemper R, Kohler HR, et al. (2004). Toxic effects of the non-steroidal anti-inflammatory drug Diclofenac part II. Cytological effects in liver, kidney, gills and intestine of rainbow trout (Oncorhynchus mykiss). Aquat Toxicol 68: 151-166.

27. Parolini M, Binelli A, Cogni D, Riva C, Provini A (2009) An in vitro biomarke approach for the evaluation of the ecotoxicity of non-steroidal anti-inflammatory drugs (NSAIDs). Toxicol in Vitro 23: 935-942.

28. Parolini M, Binelli A, Provini A (2011) Assessment of the Potential CytoGenotoxicity of the Nonsteroidal Anti-Inflammatory Drug (NSAID) Diclofenac on the Zebra Mussel (Dreissena polymorpha). Water Air Soil Pollut 217: 589-601.

29. Schmidt W, O'Rourke K, Hernan R, Quinn B (2011) Effects of the pharmaceuticals gemfibrozil and Diclofenac on the marine mussel (Mytilus spp.) and their comparison with standardized toxicity tests. Mar Pollut Bull 62: 1389-1395.

30. Sarikaya R, Yuksel M (2008) Genotoxic assessment of oxcarbazepine and Carbamazepine in drosophila wing spot test. Food Chem Toxicol 46: 3159 3162.

31. Ambrosio AF, Silva AP, Araujo I, Malva JO, Silva PS, Carvalho AP, Carvalho CM (2000) Neurotoxic and neuro protective profile of Carbamazepine oxcarbazepine and two new putative antiepileptic drugs, BIA 2-093 and BIA 2-024. Eur J Pharmacol 406: 191-201.
32. Stefan $\mathrm{H}$, Feuerstein TJ (2007) Novel anticonvulsant drugs. Pharmacol Therap 113: 165-183.

33. Gao XM, Chuang DM (1992) Carbamazepine-induced neurotoxicity and its prevention by NMDA in cultured cerebellar granule cells. Neurosci Lett 135 $159-162$.

34. Laville N, Aït-Aïssa S, Gomez E, Casellas C, Porcher JM (2004) Effects of pharmaceuticals on cytotoxicity, EROD activity and ROS production in fish hepatocytes. Toxicology 196: 41-55.

35. Celik A (2006) The Assesment of Genotoxicity of Carbamazepine Using Cytokinesis-Block (CB) Micronucleus Assay in Cultured Human Blood Lymphocytes. Drug Chemic Toxicol 29: 227-236.

36. Collins AR (2004) The Comet assay for DNA Damage and Repair. Principles, Applications and Limitations. Mol Biotech 26: 249-261.

37. Frenzilli G, Nigro M, Lyons BP (2009) The Comet assay for the evaluation of genotoxic impact in aquatic environments. Mutat Res 681: 80-92.

38. Jha AN (2008) Ecotoxicological applications and significance of the come assay. Mutagenesis 23: 207-221.

39. Singh NP (2000) A simple method for accurate estimation of apoptotic cells. Exp Cell Res 256: 328-337.

40. Frenzilli G, Scarcelli V, Del Barga I, Nigro M, Förlin L, et al. (2004) DNA damage in eelpout (Zoarces viviparus) from Göteborg Harbour Mutat Res 552: 187-195.

41. Williams J, Kubelik AR, Liak KJ, Rafalski JA, Tinger AV (1990) DNA polymorphisms amplified by arbitrary primers are useful as genetic markers. Nucleic Acid Res. 18: 6531-6535.

42. Welsh J, McClelland M (1991) Genomic fingerprinting using arbitrarily prime PCR and a matrix of pairwise combinations of primers. Nucleic Acids Res 19 5275-5279.

43. Bacerrilli C, Ferrero M, Sanz F Castano A (1999) Detection of mitomycin C induced genetic damage in fish cells by use of RAPD. Mutagenesis 14: 449 456.

44. Savva D (1996) Use of DNA fingerprinting to detect genotoxic effect. Ecotox Environ Saf 41:103-106.

45. Conte C, Mutti I, Pugliesi P, Ferrarini A, Regina G, et al. (1998) DNA fingerprinting analysis by a PCR based method for monitoring the genotoxic effect of heavy metals pollution. Chemosphere 37: 2739-2749.

46. Atienzar FA, Cordi B, Donkin M, Evenden A, Jha AN et al. (2000) Comparison of ultraviolet-induced genotoxicity detected by random amplified polymorphic DNA with chlorophyll fluorescence and growth in a marine microalga, Palmaria palmate. Aquat Toxicol 50: 1-12.

47. Rocco L, Frenzilli G, Zito G, Archimandritis A, Peluso C, et al. (2010) Genotoxic effects in fish induced by pharmacological agents present in the sewage of some Italian water-treatment plants. Environ Toxicol DOI: 10.1002/tox.20607.

48. Snyder RD, Green JW (2001) A review of the genotoxicity of marketed pharmaceuticals, Mutat Res 488: 151-169.

49. Theodorakis CW (2001) Integration of genotoxic and population genetic endpoints in biomonitoring and risk assessment. Ecotoxicology 10: 245-256. 